\title{
International Medical Consensus Documents and Guidelines as the Basis for Getting Knowledge of Clinical Disciplines by Students
}

\author{
Rostyslav Sabadosh ${ }^{*}$, Marta Kupnovytska-Sabadosh
}

\begin{abstract}
The latest data on the diagnosis and treatment of patients with specific diseases are primarily accumulated in the international consensus documents and guidelines according to scientific evidence. In Ukraine, these documents are used mainly by the scientists who present the results of their clinical trials at various congresses and professional association meetings. As for Ukrainian students, the textbooks remain the main source of their knowledge; due to a long process of their preparing and publishing, they do not keep pace with rapid changes in the international documents. One way to solve the problem described is to reorient the methodology of training students. The fundamental postulates of such training should be as follows: the study of each disease semiotics should be based on the universally accepted criteria for its diagnosis described in the latest consensus documents, and the study of treatment methods for each disease should be based on the most important international guidelines according to scientific evidence. The tasks mentioned above can be implemented through teachers' focusing on information taken from the international guidelines and consensus documents, introducing references to these documents in the methodological materials for students, increasing students' English proficiency, creating database for the exams on the basis of the international guidelines and consensus documents, and clear agreement of Ukrainian and international medical terminology. The implementation of all the above mentioned is not an easy task, as the introduction of any changes requires appropriate funding including labor compensation for those who provide this introduction. However, without an operative system of acquainting students with the latest achievements in medical science supported by consensus documents of the universally recognized international medical organizations, Ukrainian medicine will not be able to keep pace with global medicine, and medical graduates, at the start of their career, will lag behind their colleagues abroad.
\end{abstract}

\section{Keywords}

consensus documents; guidelines; medical education.

Ivano-Frankivsk National Medical University, Ivano-Frankivsk, Ukraine

*Corresponding author: r.sabadosh@gmail.com

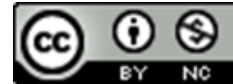

Copyright (C)Rostyslav Sabadosh, Marta Kupnovytska-Sabadosh, 2019

\section{Introduction}

Nowadays, the latest data on the diagnostics and treatment of patients with specific diseases are primarily accumulated in the international consensus documents and guidelines. They are of special importance since they are based on the principles of evidence-based medicine (EBM) [1,2]. EBM is known to be an approach to medical practice when a physician, while diagnosing a specific disease and treating a specific patient, uses only the methods the usefulness of which was confirmed by clinical trials. The difference between consensus documents and guidelines is as follows: according to the Council of Europe, a medical consensus is a public statement on the latest medical knowledge that is generally agreed upon as an evidence-based knowledge by 
a representative group of experts in that area [3], while medical guidelines are specific instructions or recommendations on determining a course of action for using knowledge mentioned above in practice [4].

The objective of the research is to introduce the system of training students in medical institutions that would provide the fastest and most complete students' awareness of the latest international consensus documents and guidelines on the diagnostics and treatment of different diseases.

\section{Discussion}

After gaining its independence, Ukraine inherited medicine sharply delimited from the outside world [5]. The research works conducted by Ukrainian medical scientists often were of universal significance even before Ukraine gained independence [6]; however, in most cases, they were not appreciated at the international level due to the isolation of the Soviet space. On the other hand, a significant amount of important medical information was inaccessible to Ukrainian medical specialists due to the lack of foreign literature and artificially created language barrier. All these processes were reflected in the field of medical pedagogy. The textbooks for medical students were primarily based on the achievements of national science without considering the international consensus documents on the diagnosis and treatment of a specific pathology.

After Ukraine gained independence, an active integration of Ukrainian medicine into global medicine started [7]. Professional associations, most of which were integrated in analogous international structures, were created in each of its fields. The organization of various conferences with international participation by these associations allowed a lot of doctors to get acquainted with the international therapeutic and diagnostic approaches. The rapid development and accessibility of information technology contributed to this process as well. In clinical practice, the processes mentioned above occur rather quickly, while in the field of medical pedagogy, these changes are hardly noticeable. New textbooks are often Ukrainian translations of old textbooks published in Russian; although they consider the achievements of international medicine, in most cases, information is out-of-date. On the one hand, this is due to the rapid development of global medical science resulting in frequent updating of the international guidelines and consensus documents; on the other hand, this is due to a long and relatively costly process of preparing material for and publishing new textbooks. As a result, Ukrainian medical students often receive incomplete knowledge on the diagnostics of different diseases and, in most cases, out-of-date information on their treatment. All this can be considered as one of the biggest challenges in Ukrainian medical pedagogy as, under such conditions, at the start of their career, young Ukrainian doctors will lag behind their colleagues from the countries where this problem was solved.

One way to solve the problem described is to reorient the methodology of training students. The fundamental postulates of such training should be as follows: the study of each disease semiotics should be based on the universally accepted criteria for its diagnosis described in the latest consensus documents, and the study of treatment methods for each disease should be based on the most important international guidelines according to scientific evidence.

The training of students in compliance with the postulates mentioned above requires the following steps.

Firstly, it is achieving a high level of English proficiency, and especially proficiency in English medical terminology, by students. We should clearly understand that English now assumed a leading role as the international language of medicine rather than Latin. Almost all international guidelines and consensus documents are published in English language. Therefore, the External Independent Evaluation in English should be mandatory for admission to medical institutions, and the study of professional English should be mandatory for all medical students. This does not mean that Latin is not a language worth studying. A great number of universally accepted fundamental works use Latin terminology itself, and the lack of knowledge of Latin will also limit the possibilities of students' professional enrichment. However, priority should be 
given to the study of English medical terminology.

Secondly, Ukrainian and international medical terminology should be clearly agreed. The articles written by Ukrainian scientists, as well as UkrainianEnglish medical dictionaries often contain direct translations of different diseases, anatomical structures, surgical interventions etc., rather than correct translations of medical terms. This situation is unacceptable as it results in significant misunderstandings and inaccuracies when describing the results of research works by scientists, thereby creating significant obstacles for the student when trying to quickly find the necessary material. Considering this, both the Ministry of Health of Ukraine and all the professional associations must carefully monitor all the changes in international medical terminology and nomenclature and reflect them immediately in national terminology and nomenclature. Only in this case, we will be understood by foreign scientists, and our students will be able to easily find all the information they need.

Thirdly, the methodological materials for students of each department of higher medical educational institutions should contain the latest international consensus documents and guidelines in the list of the sources recommended to master the material studied.

Fourthly, during practical classes or when delivering lectures, the tutors should emphasize these documents. Since, according to the curriculum of the final year of study in higher medical educational institutions, students revise and refresh their knowledge of clinical disciplines, changes in the international consensus documents and guidelines should be the main thing considered by teachers and students.

Fifthly, the main block of tests, case studies, practical skills and theoretical questions of the final module controls should be based on the latest international consensus documents and guidelines. Similarly, these documents should be basic when creating test block for the medical licensing exam "Krok 1-3".

The implementation of all the above mentioned is not an easy task, as the introduction of any changes requires appropriate funding including labor com- pensation for those who provide this introduction. Considering the current state of national medicine funding, we realize that it will be a difficult task. At the same time, we are sure that without an operative system of acquainting students with the latest achievements in medical science supported by consensus documents of the universally recognized international medical organizations, Ukrainian medicine will not be able to keep pace with global medicine, and medical graduates, at the start of their career, will lag behind their colleagues abroad.

\section{Conclusions}

1. Under current conditions of global medicine development, the study of each disease semiotics by students should be based on the universally accepted criteria for its diagnosis described in the latest consensus documents, and the study of treatment methods for each disease should be based on the most important international guidelines according to scientific evidence.

2. The tasks mentioned above can be implemented through teachers' focusing on information taken from the international guidelines and consensus documents, introducing references to these documents in the methodological materials for students, increasing students' English proficiency, creating database for the exams on the basis of the international guidelines and consensus documents, and clear agreement of Ukrainian and international medical terminology.

\section{References}

[1] Burgers JS, Grol R, Klazinga NS et al. Towards evidence-based clinical practice: an international survey of 18 clinical guideline programs. Int J Qual Health Care. 2011;15(1):3134. DOI: https://doi.org/10.1093/ intqhe/15.1.31 [PMid:12630799]

[2] AGREE Collaboration. Development and validation of an international appraisal instrument for assessing the quality of clinical practice 
guidelines: the AGREE project. Qual Saf

Health Care. 2003;12(1):18-23. DOI: https :

//doi.org/10.1136/qhc.12.1.18

[PMid:12571340 PMCid:PMC1743672]

[3] Council of Europe. Developing a methodology for drawing up guidelines on best medical practice. Recommendation Rec13 and explanatory memorandum. Strasbourg: Council of Europe Publishing; c2002. 78p.

[4] De Boeck K, Castellani C, Elborn JS. Medical consensus, guidelines, and position papers: A policy for the ECFS. Journal of Cystic Fibrosis. 2014.13(5):495498. DOI: https://doi.org/10.1016/ j.jcf.2014.06.012 [PMid:25053447]

[5] Stupak FYa. Health development in Ukraine in the second half of the twentieth century. Grani. 2015;118(2):158-162. [published in Ukrainian]

[6] Hanitkevych Ya. Ukraiinskyi medychnyi kalendar. Kyiv: Nationalna medychna biblioteka Ukraiiny; c2016. 220p.

[7] Vashchuk FH. Intehratsiia v yevropeiskyi osvitnii prostir: zdobutky, problemy, perspektyvy: Monohrafiia. Vashchuk FH, editor. Yevrointehratsiia: ukraiinskyi vymir. c2011. 560p.

Received: 2019-12-09

Revised: $2019-12-17$

Accepted: 2019-12-18 